\title{
Effect of Dietary Zinc-Methionine on Growth, Carcass Traits, Antioxidants and Immunity of Growing Rabbits El-Moghazy, M. M. ${ }^{1}$; H. A. El-Fadaly ${ }^{2}$; E. I. Khalifa ${ }^{3}$ and M. A. Mohamed ${ }^{1}$ ${ }^{1}$ Department of Animal Production, Faculty of Agriculture, Dameitta University, Dameitta, Egypt \\ ${ }^{2}$ Department of Microbiology, Faculty of Agriculture, Dameitta University, Dameitta, Egypt. \\ ${ }^{3}$ Animal Production Research Institute, Agricultural Research Center, Egypt.
}

\section{ABSTRACT}

Effect of dietary zinc-methionine (Zn-Me), on growth performance, carcass characteristics, anti-oxidant status, immunity, liver and kidney functions of NZW growing rabbits was studied. Total of 80 rabbits were assigned into 4 groups fed basal diet with 0 (G1), 50 (G2), 100 (G3) and 150 (G4) mg of Zn-Me/kg diet, respectively. The average of body weight, weight gain, daily feed intake and feed conversion, performance index and viability rate were recorded at age intervals from 5 to $13 \mathrm{wk}$. The carcass characteristics, hematological and biochemicals, anti-oxidant and Immunoglobulins in serum were determined at the termination of the experimental period (13 wk). Results revealed that $\mathrm{Zn}-\mathrm{Me}(100 \mathrm{mg} / \mathrm{kg}$ diet) addition increased $(\mathrm{P}<0.05)$ growth performance (body weight of rabbits at 9 and $13 \mathrm{wk}$ of age, and daily gain of rabbits at $5 \sim 13 \mathrm{wk}$ of age interval), hemoglobin, red blood cells, platelets and hematocrit, and neutrophils and eosinophils, serum total proteins, glucose, total anti-oxidant capacity, glutathione reduced, glutathione S-transferase and superoxide dismutase, and immunoglobulins concentrations. The count of blood cells and lymphocytes, monocytes and acidophils percentages, and triglycerides, creatinine, urea concentrations, and enzyme activity and thiobarbituric acid-reactive substances concentration decreased $(\mathrm{P}<0.05)$ as affected by $\mathrm{Zn}-\mathrm{Me}(100 \mathrm{mg} / \mathrm{kg}$ diet $)$. The carcass net weight, dressing percentages (based on carcass net carcass weight or plus edible organs), and spleen and heart weight percentages were $(\mathrm{P}<0.05)$ the highest in $\mathrm{G} 3$ compared with other groups. In conclusion, dietary supplementation with zinc-methionine (100 mg/kg diet) can improve growth performance, lipid profile, immunity and anti-oxidant status, without adversely effects on kidney and liver functions of growing rabbits.

Keywords: rabbits, zinc-methionine, growth performance, anti-oxidant status, immunity.

\section{INTRODUCTION}

Among different livestocks, rabbit has a great attention due to their notability in meat production, and productive, reproductive and economic efficiencies (Basavaraj et al., 2011; El-Ratel, 2017). Rabbit meat considered as a vital protein source for human consumption due to its high quality, low fat and low cholesterol content (Jones, 1990). For maximizing production of rabbit meat, there is a wide need for necessary dietary additives to improve growth performance of growing rabbits (Hassan et al., 2017).

Trace minerals have important part in enhancing growth efficiency, reproductive performance and immunity of animals (Suttle, 2010). Zinc (Zn) as a trace element contributes in several biological processes, for normal growth, development of bone, feathering, immune response, regulation of appetite and activity of many enzymes of body metabolism, e.g. carbohydrate, energy, and protein (Sahin et al. 2009; Salim et al. 2011). In addition, $\mathrm{Zn}$ plays a necessary role in the anti-oxidant defense system, through it is a component of superoxide dismutase (Powell, 2000), and increasing a cystine-rich protein as a scavenger of free radical (Oteiza et al., 1996).

The $\mathrm{Zn}$ is absorbed in the small intestine and an intestinal pool of $\mathrm{Zn}$ may be formed by binding the metal to the intestinal metallothionein or Zn may be transported by albumin plasma to the liver (Prasad, 1993). A family of $\mathrm{Zn}$ transporters that play an important role in the regulation of $\mathrm{Zn}$ metabolism at the intracellular level in mammalians has been described. They structurally consist of six transmembrane domains, an intracellular histidine-rich region, and the amino and carboxy terminus, which resides intracellularly (Tako et al., 2005).

Animals requirement micro-elements in small amounts, and these micro-elements play an important function in all processes of physiological, from bone structure to maintaining the proteins and lipids structure In the intensive production, their addition is obligatory, since it has been the only way to provide them in sufficient amounts required for health and production optimums (Pajtáš et al., 2009; Chrastinová et al, 2015).

Because many natural food ingredients show marginal $\mathrm{Zn}$ deficiency, this micronutrient is commonly supplemented to diets for animals. Regardless of the fact that certain micro-elements are present in food in sufficient quantities, subclinical or clinical symptoms of their deficiency appear. This can be caused by their different and changeable availability, or the micro-elements are present in form that cannot be used. Obtained results showed that the presence of certain substances in food (phytic acid and oxalic acid), as well as interaction with other nutrients in the digestive tract, influences resorption mechanisms. Resorption of micro-elements is not dependent only on their content in food, but also on the animals' age, electrochemical reactions in the intestine and on the microelement form. Mineral salts, such as oxides, carbonates, chlorides and sulphates are most frequently used. Today, in supplementation of in-organic forms of minerals, the use of so-called "chelate"forms, i.e. organically bonded micro-elements, is becoming more frequent. Enteric diseases frequently occur in rabbits around the weaning period, leading to an extensive use of antibiotics. Therefore, anti-microbial agents are searched for to prevent and/or overcome infections. Prevention and treatment of clostridial infections by natural substances or phyto-additives are important because of animal mortality and economic losses (Chrastinová et al., 2010; Chrastinová et al., 2016; Marcin et al., 2006).

Zinc-methionine (Zn-Me) is organic-zinc, which is freed from free divalent cations for chelation in intestinal lumen by phytic-acid. Thus it is metabolized in a various processes which facilitate improve $\mathrm{Zn}$ absorption (Burrell et al., 2004). In this line, Zn-Me could be beneficially incorporated at lower levels in broiler diet compared with inorganic-Zn for catching higher $\mathrm{Zn}$ bioavailability, and 
lowering excretion of $\mathrm{Zn}$ to environment (Sunder et al., 2013).

Therefore, the effect of dietary supplementing different levels of $\mathrm{Zn}-\mathrm{Me}(0,50,100$ and $150 \mathrm{mg} / \mathrm{kg}$ diet $)$ on productive, carcass characteristics, blood biochemicals, enzyme activity, anti-oxidant and immunity capacity in growing rabbits were investigated.

\section{MATERIALS AND METHODS}

The current experiment was conducted at a private rabbit farm, Dakahlia Governorate, in co-operation with Faculty of Agriculture, Animal Production Department, Damietta University.

Weaned rabbits $(n=80)$ were similarly divided into four groups (20/group). All NZW rabbits used in this study aged five wks at the start of the experiment and averaged $678.71 \pm 3.707 \mathrm{~g}$ live body weight (LBW). All rabbits were exposed to similar managerial and environmental conditions. Rabbits were kept in community battery cages with ten replicates ( 2 /cage of the same sex), in wire cages $(25 \times 50 \times 35 \mathrm{~cm})$, install in a close rabbit house with suitable ventilation.

Rabbits in the $1^{\text {st }}$ group were fed on commercial pelleted diet as a basal diet (BD) without supplementation (G1, control). Rabbits in the $2^{\text {nd }}(\mathrm{G} 2), 3^{\text {rd }}(\mathrm{G} 3)$ and $4^{\text {th }}(\mathrm{G} 4)$ groups were fed on BD supplemented with 50, 100 and $150 \mathrm{mg}$ of Zinc-methionine (Zn-Me)/kg diet, respectively. The weekly amount of each experimental diet was well mixed with their determined level of $\mathrm{Zn}-\mathrm{Me}$ in homogenous form. The experimental period continue from 5 - 13 wk of age.

The BD was formulated to cover all fundamental, nutrient requirements for growing rabbit (De Blas and Mateos, 1998). Ingredients of BD included berseem hay $(33 \%)$, barley grain $(24.6 \%)$, wheat brain $(17 \%)$, soybean meal (17\%), molasses (3\%), Di-calcium phosphate $(1.6 \%)$, limestone $(1 \%)$, DL-methionine $(0.2 \%)$, sodium chloride $(0.5 \%)$, premix $(0.3 \%)$ and contained $17.36 \% \mathrm{CP}, 13.45 \%$ $\mathrm{CF}, 1.61 \%$ EE, $61.77 \%$ NFE, 5.81\% ASH and 2412 $\mathrm{Kcal} / \mathrm{Kg}$ diet as digestible energy

The LBW and feed intake (FI) were recorded at 5, 9 and 13 wk of age, then average daily gain (ADG) and feed conversion ratio (FCR) were calculated at age intervals 5 to 9,9 to13 and 5 to13 wk. Dead bunnies number during the experimental period was recorded, while viability rate (VR) was calculated. Performance index $(\mathrm{PI})$ was calculated as the following:

$\mathbf{P I}=($ Final LBW $(\mathrm{kg}) /$ feed conversion ratio) $\mathbf{x 1 0 0}$.

Samples of blood were collected at the termination of the experimental period (13 wk of age), from five rabbits/ group during slaughter, into two test tubes for each animal, one with heparin for hematological parameters and another test tube without heparin for other blood parameters in blood serum. Concentration of hemoglobin $(\mathrm{Hb})$, value of hematocrit $(\mathrm{Ht})$, red $(\mathrm{RBCs})$ and white (WBCs) blood cells count and platelets. Also, Erythrocytic index, including mean corpuscular volume, mean corpuscular hemoglobin and mean corpuscular hemoglobin concentration in whole blood samples were determined (Wintrobe, 1967). Lymphocytes, monocytes, eosinophils and neutrophils percentages were determined (Lucky, 1977).

The collected blood samples in clean tube without anti-coagulant were centrifuged (3000 rpm for $20 \mathrm{~min}$ ), then blood serum was isolated and kept at $-20^{\circ} \mathrm{C}$ until assayed. Total protein (TP), albumin (AL), glucose, cholesterol, triglycerides, high (HDL) and low (LDL) density lipoproteins, creatinine and urea concentrations, activity of aspartate (AST) and alanine (ALT) transaminases were determined using (Bio-Merieux, Laboratory Reagents and Products, France). Concentration of globulin (GL) was obtained by difference between TP and AL. Total antioxidant capacity (TAC), glutathione content (GSH), glutathione peroxidase (GPx), glutathione S-transferase (GST), superoxide dismutase (SOD) and thiobarbituric acid-reactive substances (TBARS) were assayed in serum by available kits (Bio Diagnostic Research). Concentration of immunoglobulins in blood serum was determined by commercial ELISA kits (Kamiya Biomedical Company, USA).

Five rabbits per group were chosen, fasted for $12 \mathrm{~h}$, weighed and slaughtered to estimate carcass characteristic at $13 \mathrm{wk}$ of age. Weights of carcass parts and body internal organs and calculated relative to LBW of each rabbit.

Data were statistically analyzed by one-way ANOVA design (SAS, 2002). Mortality rate were statistically analyzed using Chi-Square test. The percentage values were transformed by arcsine values before analysis. The group significant differences were tested by Duncan's multiple range test (Duncan 1955) and set at $\mathrm{P}<0.05$.

\section{RESULTS AND DISCUSSION}

\section{Growth performance parameters:}

Results in Table (1) revealed that live body weight (LBW) of rabbits at 9 and 13 wk of age, and average daily gain (ADG) of rabbits at 5 13 wk of age interval were $(\mathrm{P}<0.05)$ higher in $\mathrm{G} 2$ and $\mathrm{G} 3$ than in $\mathrm{G} 1$ and $\mathrm{G} 4$. However, the effect of $\mathrm{Zn}-\mathrm{Me}$ on daily feed intake (FI), feed conversion ratio (FCR), performance index and viability rate were not significant at all age intervals, except feed conversion ratio during 9 13 wk was $(\mathrm{P}<0.05)$ the best in G3 than in other group (Table 1).

These results indicated beneficial effects of dietary supplementation of $\mathrm{Zn}-\mathrm{Me}$ (100 $\mathrm{mg} /$ diet) on growth performance of growing rabbits. In accordance with these findings, Hrastinová et al. (2018) showed that the addition of $50 \mathrm{mg} \mathrm{Zn} / \mathrm{kg}$ diet is sufficient to achieve optimal growth performance, increased FCR $(\mathrm{P}<0.05)$ and $\mathrm{ADG}$ of growing rabbits. Also, Amen and Sulaiman (2016) found that $\mathrm{ADG}$ and final LBW of rabbits treated with dietary $\mathrm{Zn}$ supplementation were $(\mathrm{P}<0.05)$ increased compared with control. While, FI were not significant by treatment with $\mathrm{Zn}$ and control groups. The dietary $\mathrm{Zn}$ levels $(100 \mathrm{mg} / \mathrm{kg})$ significantly increased LBW and ADG, but had no effect on daily FI as compared to control (Ayyat and Marai, 2000). However, Dietary Zn levels (50, 100 or $200 \mathrm{mg} / \mathrm{kg}$ diet) had no significant effect on FCR of growing rabbits at 13 wk (Ayyat and Maria, 2000; Nessrin et al., 2012). 
Table 1. Effect of dietary zinc-methionine supplementation on growth performance of growing rabbits at different

\begin{tabular}{|c|c|c|c|c|c|c|}
\hline \multirow{2}{*}{ Item } & \multirow{2}{*}{$\begin{array}{c}\text { G1 } \\
\text { (Control) }\end{array}$} & \multicolumn{3}{|c|}{ Experimental group } & \multirow{2}{*}{ SEM } & \multirow{2}{*}{ P-value } \\
\hline & & G2 (50 mg Zn-Me/kg) & G3 (100 mg Zn-Me /kg) & G4 (150 mg Zn-Me /kg) & & \\
\hline \multicolumn{7}{|c|}{ Average live body weight ( $\mathrm{g}$ ) } \\
\hline At $5 \mathrm{wk}$ (Initial) & 677.56 & 678.71 & 678.65 & 680.65 & 3.707 & 0.9485 \\
\hline At 9 wk & $1372.38^{\mathrm{c}}$ & $1394.94^{\mathrm{ab}}$ & $1404.88^{\mathrm{a}}$ & $1388.18^{\mathrm{b}}$ & 3.922 & 0.0001 \\
\hline At 13 wk (Final) & $2094.25^{\mathrm{c}}$ & $2123.94^{\mathrm{b}}$ & $2147.41^{\mathrm{a}}$ & $2099.18^{\mathrm{c}}$ & 3.982 & 0.0001 \\
\hline \multicolumn{7}{|l|}{ Average daily gain $(\mathrm{g})$} \\
\hline At $5 \sim 9 \mathrm{wk}$ & $24.82^{\mathrm{d}}$ & $25.58^{\mathrm{b}}$ & $25.94^{\mathrm{a}}$ & $25.27^{\mathrm{c}}$ & 0.034 & 0.0001 \\
\hline At $9 \sim 13 \mathrm{wk}$ & $25.78^{\mathrm{c}}$ & $26.04^{\mathrm{b}}$ & $26.52^{\mathrm{a}}$ & $25.39^{\mathrm{d}}$ & 0.031 & 0.0001 \\
\hline At $5 \sim 13 \mathrm{wk}$ & $25.29^{c}$ & $25.81^{\mathrm{b}}$ & $26.21^{\mathrm{a}}$ & $25.33^{\mathrm{c}}$ & 0.025 & 0.0001 \\
\hline \multicolumn{7}{|c|}{ Average daily feed intake (g) } \\
\hline At $5 \sim 9 \mathrm{wk}$ & 64.50 & 64.47 & 64.35 & 63.94 & 1.003 & 0.9775 \\
\hline At $9 \sim 13 \mathrm{wk}$ & 112.56 & 111.76 & 111.53 & 111.24 & 1.334 & 0.9110 \\
\hline At $5 \sim 13 \mathrm{wk}$ & 88.53 & 88.12 & 87.94 & 87.59 & 0.726 & 0.8348 \\
\hline \multicolumn{7}{|c|}{ Feed conversion ratio (g feed/g gain) } \\
\hline At $5 \sim 9 \mathrm{wk}$ & 2.60 & 2.52 & 2.48 & 2.53 & 0.060 & 0.7858 \\
\hline At $9 \sim 13 \mathrm{wk}$ & $4.36^{\mathrm{a}}$ & $4.29^{\mathrm{ab}}$ & $4.21^{\mathrm{b}}$ & $4.38^{\mathrm{a}}$ & 0.059 & 0.0360 \\
\hline At $5 \sim 13 \mathrm{wk}$ & 3.50 & 3.41 & 3.36 & 3.46 & 1.879 & 0.4314 \\
\hline Performance index (\%) & 59.91 & 62.29 & 63.91 & 60.67 & 1.888 & 0.8254 \\
\hline Viability rate* & 80 & 85 & 90 & 90 & - & - \\
\hline
\end{tabular}

In goats, Kundu et al. (2014) found significantly higher LBW at birth and ADG of kids born from dams receiving 50 or $100 \mathrm{ppm}$ of $\mathrm{Zn}$ compared with those of control. In sheep, ewes supplemented with $100 \mathrm{ppm} \mathrm{Zn}$ improved LBW of their lambs at birth and weaning compared with control ewes (Ali et al., 1998). Recently, (Saleh et al. (2018) concluded that dietary Zn-Me supplementation increased LBW and ADG, and enhanced FCR in broilers. Also, Sahin et al. (2005) presumed that Zn picolinate addition (30 or $60 \mathrm{mg} / \mathrm{kg}$ ) enhanced parameters in to heat stress quails.

Zinc is a very important trace element that is involved in a wide range of metabolic activities and productive performances as a growth (Underwood and Suttle, 1999). One possible demonstration for such enchantments might be related to $\mathrm{Zn}$ is considered of critical importance in maintaining the structure of metalloproteins like insulin, growth hormone and growth factor (Khan et al. 2014; Midilli et al. 2014).

\section{Blood parameters:}

Hematological parameters:

Treatment of rabbit with $\mathrm{Zn}-\mathrm{Me}$ at a level of (100 $\mathrm{mg} / \mathrm{kg})$ increased $(\mathrm{P}<0.05) \mathrm{Hb}$ concentration, RBCs count, platelets and $\mathrm{Ht}$ value, and percentages of neutrophils and eosinophils, while decreased $(\mathrm{P}<0.05) \mathrm{WBCs}$ count and percentages of lymphocytes, monocytes and acidophils in G3 compared with other groups. While erthrocytic values of mean corpuscular volume, mean corpuscular hemoglobin and mean corpuscular hemoglobin concentration were not affected $(\mathrm{P} \geq 0.05)$ by $\mathrm{Zn}-\mathrm{Me}$ treatment. Also, treatment of rabbit with $\mathrm{Zn}-\mathrm{Me}$ at a level of $(50 \mathrm{mg} / \mathrm{kg})$ significantly improved $(\mathrm{P}<0.05)$ all previous traits as compared to $\mathrm{G} 1$, while increasing Zn-Me level to $150 \mathrm{mg} / \mathrm{kg}$ failed to improve all hematological parameters in comparing with control group (Table 2). It is of interest to note that increasing $\mathrm{Hb}$ concentration in $\mathrm{G} 2$ and $\mathrm{G} 3$ was assigned by increasing RBCs count and value of $\mathrm{Ht}$ as affected with $\mathrm{Zn}-\mathrm{Me}$ level up to $100 \mathrm{mg} / \mathrm{kg}$. The observed decreased in WBCs count was associated with decreasing percentages of lymphocytes and acidophils, and marked increase in neutrophils (Table 2).

Hematological parameters are good indicators of rabbit physiological status (Khan and Zafar, 2005). In this respect, $\mathrm{Ht}, \mathrm{Hb}$ and $\mathrm{MCH}$ are major indices for evaluating circulatory erythrocytes (Chineke et al., 2006). Lymphocytes are considered the main WBCs types and a good indicator of the immune response (Wieslaw et al., 2006).

In comparable with the present results on rabbits, Ahmed et al. (1997) showed that RBCs count and Ht values were increased significantly by copper addition of growing rabbit diet. In this respect, $\mathrm{Zn}$ has significant role in $\mathrm{Hb}$ formation and hence, more $\mathrm{Zn}$ availability in organic $\mathrm{Zn}$ supplemented group might have promoted better $\mathrm{Hb}$ synthesis in treatment group in goat (Chavan et al., 2016). Also, Shinde et al. (2012) and Mondal et al. (2013) showed similar results in adult rams and lambs, respectively.

The role of reactive oxygen species (ROS) in the mechanism of RBCs damage in diabetic patients was implicated by Palmieri et al. (2001). Thus, enhancing most erythrocytic index after $\mathrm{Zn}-\mathrm{Me}$ treatment in this paper, might be related to the strong anti-oxidant effect of $\mathrm{Zn}$ on hematopoietic cells, which appears to be particularly vulnerable in the presence of unchecked accumulation of ROS (Fathi et al., 2016).

\section{Blood biochemicals:}

Data of protein fractions, carbohydrate metabolism and lipid metabolism indicated better healthy status function of rabbits in $\mathrm{G} 2$ and G3, being the best in G3, in terms of increase $(\mathrm{P}<0.05)$ in $\mathrm{TP}$ and glucose concentrations and reducing triglycerides, creatinne and urea concentrations, and AST and ALT activities. However, there were insignificant differences in serum albumin, globulin, albumin/globulin ratio, cholesterol, HDL and LDL concentrations (Table 3). 
Table 2. Effect of dietary zinc-methionine supplementation on hematological parameters of growing rabbits at 13 weeks of age.

\begin{tabular}{|c|c|c|c|c|c|c|}
\hline \multirow{2}{*}{ Parameter } & \multirow{2}{*}{$\begin{array}{c}\text { G1 } \\
\text { (Control) }\end{array}$} & \multicolumn{2}{|c|}{ Experimental group } & \multirow[b]{2}{*}{ G4 (150 mg Zn-Me /kg) } & \multirow{2}{*}{ SEM } & \multirow[b]{2}{*}{ P-value } \\
\hline & & G2 (50 mg Zn-Me /kg) & G3 (100 mg Zn-Me /kg) & & & \\
\hline $\mathrm{RBCs}\left(\times 10^{6} / \mathrm{mm}^{3}\right)$ & $4.93^{\mathrm{c}}$ & $5.24^{\mathrm{b}}$ & $5.73^{\mathrm{a}}$ & $4.98^{\mathrm{c}}$ & 0.0181 & 0.0001 \\
\hline WBCs $\left(\times 10^{3} / \mathrm{mm}^{3}\right)$ & $7.15^{\mathrm{a}}$ & $6.87^{\mathrm{c}}$ & $6.31^{\mathrm{d}}$ & $7.01^{\mathrm{b}}$ & 0.0307 & 0.0001 \\
\hline Platelets $\left(\times 10^{3} / \mathrm{mm}^{3}\right)$ & $222.67^{\mathrm{c}}$ & $236.00^{\mathrm{b}}$ & $251.00^{\mathrm{a}}$ & $230.00^{\mathrm{bc}}$ & 2.3511 & 0.0002 \\
\hline Hemoglobin (mg/dl) & $9.40^{\mathrm{c}}$ & $9.85^{\mathrm{b}}$ & $10.57^{\mathrm{a}}$ & $9.45^{\mathrm{c}}$ & 0.0278 & 0.0001 \\
\hline Hematocrit (\%) & $37.33^{\mathrm{b}}$ & $41.67^{b}$ & $48.33^{\mathrm{a}}$ & $39.00^{\mathrm{b}}$ & 1.5811 & 0.0002 \\
\hline \multicolumn{7}{|l|}{ Erythrocytic index } \\
\hline $\operatorname{MCV}(\mu 3)$ & 62.67 & 63.30 & 63.61 & 63.00 & 3.5590 & 0.9974 \\
\hline $\mathrm{MCH}(\mathrm{pg})$ & 20.33 & 21.33 & 21.00 & 20.67 & 2.5980 & 0.9934 \\
\hline $\operatorname{MCHC}(\mathrm{g} / \mathrm{dl})$ & 33.10 & 33.30 & 33.63 & 33.23 & 2.2395 & 0.9985 \\
\hline \multicolumn{7}{|l|}{ Leucocyte fraction (\%): } \\
\hline Lymphocytes & $57.27^{\mathrm{a}}$ & $51.66^{\mathrm{b}}$ & $48.89^{c}$ & $51.64^{\mathrm{b}}$ & 1.1335 & 0.0008 \\
\hline Monocytes & $6.01^{\mathrm{a}}$ & $5.24^{\mathrm{b}}$ & $5.39^{\mathrm{b}}$ & $5.11^{\mathrm{b}}$ & 0.1617 & 0.0149 \\
\hline Neutrophils & $33.24^{\mathrm{b}}$ & $39.33^{\mathrm{a}}$ & $39.80^{\mathrm{a}}$ & $39.73^{\mathrm{a}}$ & 0.1711 & 0.0123 \\
\hline Acidophils & $2.05^{\mathrm{a}}$ & $1.92^{\mathrm{b}}$ & $1.88^{\mathrm{c}}$ & $1.97^{\mathrm{b}}$ & 0.0221 & 0.0004 \\
\hline Eosinophils & $1.43^{\mathrm{d}}$ & $1.85^{\mathrm{b}}$ & $4.04^{\mathrm{a}}$ & $1.55^{\mathrm{c}}$ & 0.0256 & 0.0001 \\
\hline
\end{tabular}

Different superscripts in the same row indicate significant difference among means at $\mathrm{P}<0.05$.

Table 3. Effect of dietary zinc-methionine supplementation on biochemicals and enzyme activity in serum of growing rabbits at 13 weeks of age.

\begin{tabular}{|c|c|c|c|c|c|c|}
\hline \multirow{2}{*}{ Parameter } & \multirow{2}{*}{$\begin{array}{c}\text { G1 } \\
\text { (Control) }\end{array}$} & \multicolumn{3}{|c|}{ Experimental group } & \multirow{2}{*}{ SEM } & \multirow{2}{*}{ P-value } \\
\hline & & G2 (50 mg Zn-Me /kg) & G3 (100 mg Zn-Me /kg) & G4 (150 mg Zn-Me /kg) & & \\
\hline \multicolumn{7}{|l|}{ Blood biochemical: } \\
\hline Total proteins $(\mathrm{g} / \mathrm{dl})$ & $5.95^{\mathrm{c}}$ & $6.14^{\mathrm{b}}$ & $6.20^{\mathrm{a}}$ & $6.04^{\mathrm{bc}}$ & 0.0442 & 0.0176 \\
\hline Albumin (AL) (g/dl) & 3.48 & 3.52 & 3.54 & 3.50 & 0.0270 & 0.5015 \\
\hline Globulin (GL) (g/dl) & 2.46 & 2.61 & 2.66 & 2.54 & 0.0412 & 0.0553 \\
\hline $\mathrm{AL} / \mathrm{GL}$ ratio & 1.41 & 1.35 & 1.33 & 1.38 & 0.0261 & 0.2151 \\
\hline Glucose (mg/dl) & $72.67^{\mathrm{c}}$ & $84.66^{\mathrm{b}}$ & $98.65^{\mathrm{a}}$ & $78.33^{\mathrm{bc}}$ & 2.8480 & 0.0011 \\
\hline Total cholesterol (mg/dl) & 134.70 & 129.67 & 127.03 & 131.33 & 1.8221 & 0.0890 \\
\hline Triglycerides (mg/dl) & $124.93^{\mathrm{a}}$ & $110.00^{\mathrm{b}}$ & $87.17^{\mathrm{c}}$ & $116.00^{\mathrm{b}}$ & 2.2619 & 0.0001 \\
\hline HDL (mg/dl) & 55.33 & 61.33 & 64.00 & 58.67 & 2.3094 & 0.1265 \\
\hline $\operatorname{LDL}(\mathrm{mg} / \mathrm{dl})$ & 37.66 & 34.67 & 32.33 & 35.100 & 1.4807 & 0.1684 \\
\hline Creatinine (mg/dl) & $0.82^{\mathrm{a}}$ & $0.74^{\mathrm{bc}}$ & $0.70^{\mathrm{c}}$ & $0.78^{\mathrm{ab}}$ & 0.0162 & 0.0041 \\
\hline Urea $(\mathrm{mg} / \mathrm{dl})$ & $44.73^{\mathrm{a}}$ & $42.37^{\mathrm{a}}$ & $34.38^{\mathrm{b}}$ & $43.72^{\mathrm{a}}$ & 2.2032 & 0.0379 \\
\hline \multicolumn{7}{|l|}{ Enzyme activity (IU/l) } \\
\hline AST & $57.33^{\mathrm{a}}$ & $52.33^{\mathrm{b}}$ & $44.67^{\mathrm{c}}$ & $54.33^{\mathrm{ab}}$ & 1.3944 & 0.0012 \\
\hline ALT & $46.37^{\mathrm{a}}$ & $39.02^{\mathrm{ab}}$ & $35.33^{\mathrm{b}}$ & $41.12^{\mathrm{ab}}$ & 2.2319 & 0.0449 \\
\hline
\end{tabular}

Different superscripts in the same row indicate significant difference among means at $P<0.05$.

Borah et al. (2013) showed that serum TP concentration significantly increased by adding $500 \mathrm{ppm}$ of $\mathrm{Zn}$, while $\mathrm{AL}$ concentration was not affected by different level of $\mathrm{Zn}$ supplementation in growing pig. Also, Shinde et al. (2006) found that blood TP level increased $(\mathrm{P}<0.05)$ by $\mathrm{Zn}$ addition compared with control. Contrary, some authors found that that the concentration of TP and globulin in serum of weaning piglets were not affected by capsulated or modified $\mathrm{ZnO}$ (Wang et al., 2013: Cho et al., 2015). In comparable with the recent results of $\mathrm{Zn}-\mathrm{Me}$ supplementation in different species, Mostafa et al (2019) found significant increase in TP and AL in She-camel. Also, serum TP and AL concentrations showed significant increase in dairy calves (Dresler et al., 2016). Plasma TP increased with $\mathrm{Zn}$ dietary supplementation in broiler (Bahakaim et al., 2014).

In lactating cows, Gaafer et al. (2011) found significant increase in plasma $\mathrm{TP}, \mathrm{AL}$ and $\mathrm{GL}$ concentrations during lactation period in animals fed $\mathrm{Zn}$ Met supplemented diet $(10 \mathrm{~g} / \mathrm{h} / \mathrm{d})$. In addition, concentration of TP, AL and GL were higher in all of the Zn supplemented treatment (Shinde et al., 2006). Blood TP and $\mathrm{AL}$ concentrations during pregnancy and lactation increased $(\mathrm{P}<0.05)$ in goat does (Abu El-Ella et al., 2014) and buffaloes (Zeedan et al., 2008 and 2009) by biogen-Zn addition.

The significant increase in blood TP with Zn-Met addition may indicate increased synthesis of protein resulted from increased anabolic hormone secretion that is responsible for utilization of amino acids (El-Masry and Habeeb, 1989). In this concern, El-Masry and Marai (1991) related the differences in serum proteins to change in thyroid hormone level, and AL or GL concentrations. Increasing TP concentration might be assigned to the role of $\mathrm{Zn}$ in protein synthesis (Ibs and Rink, 2003).

In harmony with the obtained increase in glucose concentration increased $(\mathrm{P}<0.05)$ in she-camels treated with $\mathrm{Zn}-\mathrm{Me}$ (Mostafa et al., 2019), and during pregnancy and lactation periods of goats (Abu El-Ella et al., 2014) or buffaloes (Zeedan et al., 2008 and 2009) supplemented with Biogen-Zn (BZ).

In addition, Badawi et al. (2017) found that cholesterol, LDL, AL and GL concentration were not affected $(\mathrm{P} \geq 0.05)$ in birds fed the dietary $\mathrm{Zn}$ compared with control of broiler chickens. Parák and Straková (2011) found that no significant alteration in concentration of cholesterol as affected by $\mathrm{Zn}$ addition. However diets, Hazim et al. (2011) reported that $\mathrm{Zn}$ addition leads to 
increase total cholesterol. The alteration of cholesterol concentration may be due to $\mathrm{Zn}$ role in enzyme action as an integral part of several enzymes (metalloenzymes) which are important in lipid digestion and absorption.

Results of decreasing creatinine and urea concentrations as well as enzyme activities in G3 may indicate that $\mathrm{Zn}-\mathrm{Me}$ treatment had positive effect on kidney and liver function of treated rabbits, consequently healthy status of rabbits treated with $100 \mathrm{mg} / \mathrm{kg}$ diet. In disagreement with these results, Elhendy et al. (2008) found that serum concentrations of urea and creatinine were not affected by $\mathrm{Zn}$ deficiency in growing rats. Ahmadi et al. (2014) showed insignificant effects of different dietary levels of nano-ZnO in broiler on serum ALT and AST activities. While, dietary Zn-O addition improving activities of ALT and AST. The observed confliction of $\mathrm{Zn}$ treatments may be related to variation in animal species, $\mathrm{Zn}$ dose and time and duration of treatment (Sharideh et al., 2015).

\section{Anti-oxidant and immunity response:}

The TAC, GST, SOD and GSH increased $(\mathrm{P}<0.05)$, while TBARS concentration decreased $(\mathrm{P}<0.05)$ in rabbit serum in $\mathrm{G} 2$ and $\mathrm{G} 3$ than in $\mathrm{G} 1$ and $\mathrm{G} 4$, being the best in G3. Also, rabbits in G2 and G3 showed significantly $(\mathrm{P}<0.05)$ higher in $\operatorname{IgG}, \operatorname{IgM}$ and IgA concentrations than in control, reflecting higher immune response of treatment groups than in control, being the highest in G3 (Table 4).

According to the obtained results, dietary $\mathrm{Zn}-\mathrm{Me}$ supplementation up to $100 \mathrm{mg} / \mathrm{kg}$ diet improved antioxidative properties and humoral immunity in rabbits. Similar results were reported on broilers under high ambient temperature of broiler chickens (Saleh et al., 2018). Also, organic- Zn addition was increase the antioxidant enzymes activity and decrease lipid peroxidation in heat stressed poultry (Sahin et al. 2005; Khan et al. 2012; Rao et al. 2016). The GSH-Px is located firstly in the cytosol and has a general specificity in the detoxification of lipid hydro-peroxides and organic hydro-peroxides (Khan et al. 2011). Moreover, $\mathrm{Zn}$ is its preventing lipid peroxidation through inhibiting GSH depletion (Prasad 1997). The $\mathrm{Zn}$ stimulate production of $\mathrm{Zn}$-metallothionein, which is an effective scavenger for hydroxyl radical and providing protection against immune-mediated free radical attack (Laudadio et al., 2012).

Table 4. Effect of dietary zinc-methionine supplementation on antioxidant capacity, lipid peroxidation and immunoglobulins in serum of growing rabbits at 13 weeks of age.

\begin{tabular}{|c|c|c|c|c|c|c|}
\hline \multirow{2}{*}{ Parameter } & \multirow{2}{*}{ G1 (Control) } & \multicolumn{3}{|c|}{ Experimental group } & \multirow{2}{*}{ SEM } & \multirow{2}{*}{ P-value } \\
\hline & & G2 (50 mg Zn-Me /kg) & G3 (100 mg Zn-Me /kg) & G4 (150 mg Zn-Me/kg) & & \\
\hline \multicolumn{7}{|c|}{ Antioxidant parameters: } \\
\hline TAC $(\mathrm{mmol} / \mathrm{l})$ & $0.32^{\mathrm{c}}$ & $0.41^{\mathrm{b}}$ & $0.49^{\mathrm{a}}$ & $0.37^{\mathrm{bc}}$ & 0.0185 & 0.0016 \\
\hline GST (IU) & $1.23^{\mathrm{b}}$ & $1.29^{\mathrm{ab}}$ & $1.35^{\mathrm{a}}$ & $1.25^{\mathrm{b}}$ & 0.02082 & 0.0128 \\
\hline SOD (IU) & $6.29^{\mathrm{b}}$ & $6.37^{\mathrm{a}}$ & $6.40^{\mathrm{a}}$ & $6.34^{\mathrm{ab}}$ & 0.0199 & 0.0144 \\
\hline $\mathrm{GSH}(\mathrm{mg} / \mathrm{dl})$ & $14.26^{\mathrm{c}}$ & $14.44^{\mathrm{b}}$ & $14.95^{\mathrm{a}}$ & $14.34^{\mathrm{bc}}$ & 0.0294 & 0.0001 \\
\hline \multicolumn{7}{|c|}{ Lipid peroxidation $(\mathrm{nmol} / \mathrm{ml})$} \\
\hline TBARS & $1.16^{\mathrm{a}}$ & $1.09^{\mathrm{ab}}$ & $0.91^{\mathrm{c}}$ & $1.05^{\mathrm{b}}$ & 0.0280 & 0.0018 \\
\hline \multicolumn{7}{|c|}{ Immunoglobulins (mg/dl): } \\
\hline $\operatorname{IgG}$ & $519.25^{c}$ & $537.66^{\mathrm{ab}}$ & $544.65^{\mathrm{a}}$ & $534.33^{\mathrm{b}}$ & 2.6159 & 0.0008 \\
\hline $\operatorname{IgM}$ & $132.07^{\mathrm{b}}$ & $138.00^{\mathrm{b}}$ & $146.33^{\mathrm{a}}$ & $136.33^{\mathrm{b}}$ & 2.0833 & 0.0079 \\
\hline $\operatorname{IgA}$ & $155.75^{\mathrm{c}}$ & $165.74^{\mathrm{b}}$ & $178.33^{\mathrm{a}}$ & $161.67^{\mathrm{bc}}$ & 1.8906 & 0.0002 \\
\hline
\end{tabular}

Different superscripts in the same row indicate significant difference among means at $\mathrm{P}<0.05$.

In rabbits, Dietary $\mathrm{Zn}$ supplementation can modulate SOD activity (Alissa et al., 2004). The Zn addition for two months enhanced the serum levels of $\mathrm{Zn}$, anti-oxidant status, and lipid peroxidation in hemodialysis patients (Mazani et al., 2013). The positive effect might be connected with the anti-oxidative characteristic of $\mathrm{Zn}$ (Sahin et al., 2009). The $\mathrm{Zn}$ plays a key role in inhibition of ROS, because it is a co-factor of the main anti-oxidative enzyme $\mathrm{Cu}-\mathrm{Zn}$-SOD which reduce lipid peroxidation (Prasad and Kucuk, 2002). The $\mathrm{Zn}$ is necessary component of SOD enzyme, which has important role in the antioxidant defense system (Powell, 2000).

Organic-Zn supplementation enhanced the immunity response of the male guinea pigs as compared to inorganic Zn source (Shinde et al., 2006). Similarly, under heat stress, $\mathrm{Zn}$ is an important element for all aspects of immunity (Chand et al. 2014; Abudabos et al. 2017).

Dietary $\mathrm{Zn}$ supplementation increased total IgM and IgG antibody titres of broilers (Bartlett and Smith, 2003). The obtained results are in agreement with those of Chand et al. (2014), reported that anti-body titre increased $(\mathrm{P} \leq 0.05)$ due to dietary $\mathrm{Zn}$ addition. The $\mathrm{Zn}$ plays an important role in polynucleotide transcription and thus in the genetic expression process. The $\mathrm{Zn}$ also has a vital role in the immune system and affects several aspects of humoral and cellular immunity (Sunder et al., 2008). Zinc can affect thymulin secretion from the thymus gland, which stimulates production of T-cells.

\section{Carcass traits:}

Results showed that carcass net weight, dressing percentages (based on carcass net carcass weight or plus edible organs), and spleen and heart weight percentages were significantly $(\mathrm{P}<0.05)$ the highest in $\mathrm{G} 3$ compared with other groups. However, relative weights of in-edible organs were not affected significantly by $\mathrm{Zn}-\mathrm{Me}$ treatment (Table 5).

In accordance with the present results, in quails, $\mathrm{Zn}$ picolinate addition (30 or $60 \mathrm{mg} / \mathrm{kg}$ ) enhanced carcass quality (Sahin et al., 2005). However, Al-Khalifa (2006) found that additional dietary of $\mathrm{Zn}(50,100$, and $200 \mathrm{ppm})$ had no significant effect on dressing percentage of rabbits. Also, Ayyat and Marai (2000) showed that adding rabbit diets with 100,200 or $300 \mathrm{Zn} \mathrm{mg} / \mathrm{kg}$ had no effect on dressing yield compared with the control. 
Table 5. Effect of dietary zinc-methionine supplementation on carcass traits of growing rabbits at 13 weeks of age.

\begin{tabular}{|c|c|c|c|c|c|c|}
\hline \multirow{2}{*}{ Parameter } & \multirow{2}{*}{$\begin{array}{c}\text { G1 } \\
\text { (Control) }\end{array}$} & \multicolumn{2}{|c|}{ Experimental group } & \multirow[b]{2}{*}{ G4 (150 mg Zn-Me /kg) } & \multirow{2}{*}{ SEM } & \multirow{2}{*}{ P-value } \\
\hline & & G2 (50 mg Zn-Me /kg) & G3 (100 mg Zn-Me /kg) & & & \\
\hline Pre-slaughter weight (g) & $2108.80^{b}$ & $2109.400^{b}$ & $2129.60^{\mathrm{a}}$ & $2108.00^{b}$ & 5.064 & 0.0217 \\
\hline Carcass net weight (g) & $1088.60^{b}$ & $1104.20^{\mathrm{b}}$ & $1134.40^{\mathrm{a}}$ & $1093.20^{\mathrm{b}}$ & 5.663 & 0.0001 \\
\hline Dressing $(\%)^{*}$ & $51.620^{\mathrm{c}}$ & $52.345^{\mathrm{b}}$ & $53.268^{\mathrm{a}}$ & $51.858^{\mathrm{c}}$ & 0.157 & 0.0001 \\
\hline \multicolumn{7}{|c|}{ Weight of edible organs (\%): } \\
\hline Head & 5.10 & 5.15 & 5.19 & 5.13 & 0.120 & 0.9584 \\
\hline Liver & 2.57 & 2.60 & 2.61 & 2.59 & 0.098 & 0.9922 \\
\hline Kidney & 0.58 & 0.59 & 0.60 & 0.580 & 0.077 & 0.9967 \\
\hline Heart & $0.28^{\mathrm{b}}$ & $0.29^{\mathrm{b}}$ & $0.30^{\mathrm{a}}$ & $0.28^{\mathrm{b}}$ & 0.002 & 0.0001 \\
\hline Spleen & $0.04^{\mathrm{c}}$ & $0.05^{\mathrm{b}}$ & $0.05^{\mathrm{a}}$ & $0.05^{\mathrm{a}}$ & 0.001 & 0.0001 \\
\hline Testes & 0.175 & 0.179 & 0.180 & 0.176 & 0.0014 & 0.8796 \\
\hline Total & 8.748 & 8.842 & 8.94 & 8.812 & 0.2355 & 0.9524 \\
\hline Dressing $(\%)^{* *}$ & $60.37^{\mathrm{b}}$ & $61.19^{\mathrm{ab}}$ & $62.20^{\mathrm{a}}$ & $60.67^{\mathrm{b}}$ & 0.3570 & 0.0116 \\
\hline Abdominal fat $(\%)$ & 0.86 & 0.84 & 0.81 & 0.85 & 0.0795 & 0.9620 \\
\hline \multicolumn{7}{|c|}{ Weight of in-edible organs $(\%)$ : } \\
\hline Lung & 0.89 & 0.89 & 0.89 & 0.89 & 0.0030 & 0.7162 \\
\hline GIT & 0.179 & 0.182 & 0.183 & 0.182 & 0.0022 & 0.8083 \\
\hline Skin & 18.34 & 18.43 & 18.50 & 18.38 & 0.2788 & 0.9787 \\
\hline Blood & 2.84 & 2.85 & 2.86 & 2.87 & 0.1759 & 0.9998 \\
\hline Total & 40.07 & 40.40 & 40.54 & 40.29 & 0.4458 & 0.8920 \\
\hline
\end{tabular}

Different superscripts in the same row indicate significant difference among means at $\mathbf{P}<0.05$. GIT: Gastro-intestinal tract.

*Based on net carcass weight. ** Based on weight of carcass and edible organs.

\section{CONCLUSION}

Dietary supplementation with zinc-methionine at a level of $100 \mathrm{mg} / \mathrm{kg}$ diet can improve growth performance, lipid profile, immunity and anti-oxidant status of growing rabbits without adversely effects on liver and kidney function.

\section{REFERENCES}

Abu El-Ella, A. A., El-Malky O.M. and Zeedan, Kh. (2014). Studies on using biogen - zinc on productive and reproductive performance of ruminants: 1- physiological responses of damascus goats to diet supplementation with biogen-zinc. Egyp. J. Sheep \& Goat Sci., 9 (3): 29- 48.

Abudabos, A.M., Alyemni, A.H., Dafalla, Y.M. and Khan, R.U. (2017). Effect of organic acid blend and Bacillus subtilis alone or in combination on growth traits, blood biochemical and antioxidant status in broilers exposed to Salmonella typhimurium challenge during the starter phase. J Appl Anim Res.45:538-542.

Ahmadi, F., Ebrahimnezhad, Y., Sis, N.M. and Ghalehkandi, G.J.(2013). The effects of zinc oxide nanoparticles on performance digestive organs and serum lipid concentrations in broiler chickens during starter period. International Journal of Biosciences. 3(7): 23-29.

Ahmed, H., Syah, D., terMeulen, U. and Hermis, I. (1997). Effect of using copper sulphate and a feed additive on the productivity performance in growing rabbit. Tropentag. 177-180.

Alissa, E.M.,Bahijri, S.M., Lamb, D.J. and Ferns, G.A.A. (2004). The effects of coadministration of dietary copper and zinc supplements on atherosclerosis, antioxidant enzymes and indices of lipid peroxidation in the cholesterol-fed rabbit. Int J Exp Path, 85(5):265-275.

Al-Khalifa, K.H. (2006). The effect of zinc on growth performance of meat rabbit. Saudi J. Biol. Sci., 13: 71-78.

Amen, M.H.M. and Sulaiman, M. S. (2016). Effect of Zinc Supplementation on some Physiological and Growth Traits in Local Male Rabbit. World Vet. J. 6(3): 151-155.
Ayyat, M.S. and Marai, I.F. (2000).Growth performance and carcass traits as affected by breed and dietary supplementation with different zinc levels, under Egyptian conditions. Proceedings of the 7th word rabbits congress, July4- 7, Spain, pp. 83-88.

Badawi, M., Ali, M. and Behairy, A. (2017). Effects of zinc sources supplementation on performance of broiler chickens. Journal of American Science, 13(7): 35- 43.

Bahakaim, A.S.A., Abdel Magied, H.A., Osman, S.M.H., Omar, A.S., Abdel Malak, N.Y. and Ramadan, N.A. (2014). Effect of using different levels and sources of zinc in layer's diets on egg zinc enrichment. Egypt. Poulty Science. 34(I): 39-56.

Bartlett, J.R., Smith, M.O. (2003). Effects of different levels of zinc on the performance and immunecompetence of broilers under heat stress. Poult Sci. 82:1580-1588.

Basavaraj, M.,Nagabhushana, V., Prakash, N., Appannavar, M.M., Wagmare, P. and Mallikarjunappa, S. (2011). Effect of dietary supplementation of Curcuma Longa on the biochemical profile and meat characteristics of broiler rabbits under summer stress. Vet. World, 4: 15-18.

Borah, S. Sarmah, B.C. Chakravarty, P. Naskar, S. Dutta, D.J. and Kalita, D. (2013): Effect of zinc supplementation on serum biochemicals in grower pig. J Appl Anim Res, 42(2):244-248.

Burrell, A.L., Dozierrd, W.A., Davis, A.J., Complon, M.M., Freeman, M.E., Vendrell, P.F. and Ward, T.L. (2004). Responses of broilers to dietary zinc concentrations and sources in relation to environmental implications. Br Poult Sci. 45:225263.

Chand, N., Muhammad, S., Khan, R.U., Alhidary, I.A. and Rahman, Z. (2016). Ameliorative effect of synthetic $\gamma$ aminobutyric acid (GABA) on performance traits, antioxidant status and immune response in broiler exposed to cyclic heat stress. Environ Sci and Pollut Res. 23:23930-23935.

Chand, N.S., Naz Khan, A., Khan, S., Khan, R.U. (2014). Performance traits and immune response of broiler chicks treated with zinc and ascorbic acid supplementation during cyclic heat stress. Int $\mathrm{J}$ Biometeorol. 58:2153-2157. 
Chavan, S.J., Dildeep, V., Bhamare, K.S., Ravishankar, C., Babitha, V. and Sunanda, C. (2016). The effect of organic and inorganic zinc supplementation on blood haemoglobin and serum cortisol concentration in Malabari goat kids. I.J.S.N., 7 (3):611-613.

Cho, J.H. Upadhaya, S.D. and Kim, I.H. (2015): Effects of dietary supplementation of modified zinc oxide on growth performance, nutrient digestibility, blood profiles, fecal microbial shedding and fecal score in weanling pigs. Anim Sci J, 86(6):617-623.

Chrastinová, L., Chrenková, M., Lauková, A., Poláčiková, M., Simonová, M., Szabóová, R., Strompfová, V., Ondruška, L., Chlebec, I., Parkányi, V., Rafay, J., Vasilková, Z. (2010). Influence of selected phytoadditives and probiotics on zootechnical performance, caecal parameters and meet quality of rabbits. Archiva Zootecnia, 13:30-35.

Chrastinová, L., Čobanová, K., Chrenková, M., Poláčiková, M., Formelová, Z., Lauková, A., Ondruška, L., Pogány Simonová, M., Strompfová, V., Mlyneková, Z., Kalafová, A., Grešáková, L'. (2016). Effect of dietary zinc supplementation on nutrients digestibility and fermentation characteristics of caecal content in physiological experiment with young rabbits. Slovak Journal of Animal Science, 49, (1): 23-31.

Chrastinová, L., Čobanová, K., Chrenková, M., Poláčiková, M., Formelová, Z., Lauková, A., Ondruška, L., Pogány Simonová, M., Strompfová, V., Mlyneková, Z., Kalafová, A., Grešáková, L' (2015). High dietary levels of zinc for young rabbits. Slovak J. Anim. Sci., 48, (2): 57-63.

De Blas, J.C. and Mateos, G.G. (1998). Feed Formulation. In: De Blas C., Wiseman J. (Eds). The Nutrition of the Rabbit. CABI Publishing. CAB (11): 59-66.

Dresler, S., Illek, J. and Zeman1, L. (2016). Effects of organic zinc supplementation in weaned calves. Acta. Vet. Brno, 85: 049-054.

Duncan, D.B. (1955). Multiple range and Multiple F test. Biometrics, 11: 1-42.

Elhendy, H., Mokhtar, I. Y., Nasser, I. E. (2008).Effect of dietary zinc deficiency on hematological and biochemical parameters and concentrations of zinc, copper, and iron in growing rats. Toxicology 167(2):163-170.

El-Masry, K.A. and Marai, I.F. (1991). Comparison between Friesian and water buffaloes in growth rate, milk production and blood constituents during winter and summer conditions of Egypt. Anim. Prod., 53:39.

El-Ratel, I.T. (2017). Reproductive performance, oxidative status and blood metabolites of doe rabbits administrated with spirulina alga. Egypt. Poult. Sci. Vol (37) (IV): (1153-1172).

Fathi, M., Haydari, M. and Tanha, T. (2016). Effects of zinc oxide nanoparticles on antioxidant status, serum enzymes activities, biochemical parameters and performance in broiler chickens. Journal of Livestock Science and Technologies, 4 (2): 07-13.

Gaafer, H.M.A., Bassiouni, M., Ali, M.F.E., Shitta, A.A. and Shamas, A.Sh.E. (2011). Effect of zinc methionine supplementation on productive performance of lactating Friesian cows. Spanish Journal of Rural Development, II, (1): 53-62.

Hassan Fardos, A.M., Rania Mahmoud and Iman E. ElAraby (2017). Growth Performance, Serum Biochemical, Economic Evaluation and IL6 Gene Expression in Growing Rabbits Fed Diets Supplemented with Zinc Nanoparticles. Zagazig Veterinary Journal, 45 (3):238-249.
Hassan, H.M.A., Mohamed, M.A., Youssef, A.W., Hassan, E.R. (2010). Effect of using organic acids to substitute antibiotic growth promoters on performance and intestinal microflora of broilers. Asian-Australian Journal of Animal Science, 23(10)1348-1353.

Hazim, J., Mahmood, A.D., Amen, H.M. (2011). Effect of Dietary Zinc on Certain Blood Traits of Broiler Breeder Chickens. International Journal of Poultry Science. 10: 807- 813

Ibs, K.H. and Rink, L. (2003). Zinc alters immmmune function. J. Nutr. pp: 1452-1456

Jones, N.D. (1990): The developing market for farm-bred meat rabbits in Britain. Anim Prod, 50: 66A.

Khan, R.U., Naz, S. and Dhama, K. (2014). Chromium: pharmacological applications in heat stressed poultry. Internation J Pharm. 10:213-217.

Khan, R.U., Naz, S., Nikousefat, Z., Selvaggi, M., Laudadio, V. and Tufarelli, V. (2012). Effect of ascorbic acid in heat-stressed poultry. World's Poult Sci J. 68(3):477-490.

Khan, R.U., Naz, S., Nikousefat, Z., Tufarelli, V., Javdani, M., Rana, N. and Laudadio, V. (2011). Effect of vitamin E in heat-stressed poultry. World's Poult Sci J. 67 (3):469-478.

Laudadio, V., Dambrosio, A., Normanno, G., Khan, R.U., Naz, S., Rowghani, E. and Tufarelli, V. (2012). Effect of reducing dietary protein level on performance responses and some microbiological aspects of broiler chickens under summer environmental conditions. Avian Biology Res. $5(2): 88-92$.

Lucky, Z. (1977). Methods for the diagnosis of fish diseases. Ameruno Publishing Co, PVT, Ltd. New Delhi, Bomby, New York.

Macdonald, R.S. (2000). The role of zinc in growth and cell prolifereation. J Nutrit. 130:1500-1508.

Marcin, A., Sústriková, A. and Mati, R. (2006). The effects of aromatic oils on growth performance and physiological parameters in the intestine of weaned pigs. Slovak Journal of Animal Science, vol. 39, 2006, p. 103-107.

Mazani, M. ,Argani, H., Rashtchizadeh, N ., Ghorbanihaghjo, A., Hamdi, A., Estiar, M.A. and Nezami, N. (2013). Effects of zinc supplementation on antioxidant status and lipid peroxidation in hemodialysis patients. J Ren Nutr. 23(3):180-184.

Midilli, M., Salman, M., Muglali, O.H., Ögretmen, T., Cenesiz, S., Ormanci, N. (2014). The effects of organic or inorganic zinc and microbial phytase, alone or in combination, on the performance, biochemical parameters and nutrient utilization of broilers fed a diet low in available phosphorus. In J Food Agricult Vet. 8: 461-467.

Nessrin, S.A., Abdel-Khalek, M. and Gad, S.M. (2012). Effect of supplemental Zinc, Magnesium or Iron on performance and some Physiological traits of growing rabbits.Asian Journal of Poultry Science, 6(1): 23-30.

Oteiza, P. L., Olin, K. L., Fraga, C. G., Keen, C. L. (1996). Oxidant defence systems in testes from $\mathrm{Zn}$ deficient rats. Proceedings of the Society for Experimental Biology and Medicine, 213:85-91.

Pajtáš, M., Bíro, D., Horniaková, E., Beňuška, N., Šimko, M. and Juráček, M. (2009). Výživa a kŕmenie zvierat, SPU v Nitre, 150 s. ISBN 978-80-552-185-6. 
Palmieri, V., Bella, J.N., Arnett, D.K., Liu J.E. and Oberman A. (2001). Effect of type 2 diabetes mellitus on left ventricular geometry and systolic function in hypertensive subjects: Hypertension genetic Epidemiology network Hyper GEN Study. Circulation, 103: 102-107.

Parák, T. and Straková, E. (2011). Zinc as a feed supplement and its impact on plasma cholesterol concentrations in breeding cocks. Acta Veterinaria Brno. 80 (3):281-285.

Powell, S.R. (2000): The antioxidant properties of zinc. J Nutr, 130(5):1447-1454.

Prasad, A, S. (1993). Biochemistry of Zinc. Plenum Press, New Nork, NY.

Prasad, A.S. (1997). The role of zinc in brain and nerve functions. In: A. Connor, editor. Metals and oxidative damage in neurological disorders. New York (NY): Plenum Press; p. 95-111.

Prasad, A.S. and Kucuk, O. (2002). Zinc in cancer prevention. Cancer Metast Rev. 21:291-295.

Rao, R.S., Prakash, V.B., Raju, M.V.L., Panda, N.A.K., Kumari, R.K. and Reddy, E.P.K. (2016). Effect of supplementing organic forms of zinc, selenium and chromium on performance, anti-oxidant and immune responses in broiler chicken reared in tropical summer. J Biological Trace Element Res. 172:511-520.

Sahin, K., Sahin, N., Kucuk, O., Hayirli, A. and Prasad, A.S. (2009). Role of dietary zinc in heat-stressed poultry: a review. Poult Sci. 88:2176-2183.

Salgueiro, M.J., Zubillaga, M., Lysionek, A. Sarabia, M.I. Caro, R., De Paoli, T., Hager, A., Weill, R. and Boccio, J. (2000). Zinc as essential micronutrient: A review. Nutr Res, 20(5):737-755.

Salim, H.M., Lee, H.R., Jo, C., Lee, S.K. and Lee, B.D. (2011). Supplementation of graded levels of organic zinc in the diets of female broilers: effects on performance and carcass quality. Br Poult Sci. 52:606-612.

SAS. (2002). SAS Institute Inc. SAS User's Guide, Statistics. Cary, NC

Sharideh, H., Zhandi, M., Zaghari, M. and Akhlaghi A. (2015). Effect of dietary zinc oxide and phytase on the plasma metabolites and enzyme activities in aged broiler breeder hens. IJVM. 9(4): 263-270.

Sharma, V., Shukla, R.K., Saxena, N., Parmar, D., Das, M., Dhawan, A. (2009). DNA damaging potential of zinc oxide nanoparticles in human epidermal cells. Toxicol. Lett. 185(3): 211-218.
Shinde, P., Ram, S. D., Anil, K. G., Vinod, K. C. and Ripusudan, K. (2006). Effect of Zinc Supplementation from Different Sources on Growth, Nutrient Digestibility, Blood Metabolic Profile, and Immune Response of Male Guinea Pigs. Biological Trace Element Research, (112): 247-262.

Sunder, G.S., Kumar, C.V., Panda, A.K., Raju, M.L.N., Rao, S.V.R. (2013). Effect of supplemental organic $\mathrm{Zn}$ and $\mathrm{Mn}$ on broiler performance, bone measures, tissue mineral uptake and immune response at 35 days of age. Current Res in Poult Sci. 3:1-11.

Sunder, G.S., Panda, A.K., Gopinath, N.C.S., Rao, S.V.R., Raju, M.V.L.N., Reddy, M.R. and Kumar, Ch. V. (2008). Effects of higher levels of zinc supplementation on performance, mineral availability, and immune competence in broiler chickens. J Appl Poult Res, 17(1):79-86.

Suttle, N.F. (2010). The Mineral Nutrition in Livestock, 4th ed., British Library, London, UK, p. 5-113.

Tako, E., Ferket, P. R. and Uni, Z. (2005). Changes in chicken intestinal zinc exporter mRNA expression and small intestinal functionality following intraamniotic zinc-methionine administration. Journal of Nutritional Biochemistry, 16: 339-346.

Wang, C., Xie, P., Liu, L.L., Lu, J.J. and Zou, X.T. (2013). Effects of dietary capsulated zinc oxide on growth performance, blood metabolism and mineral concentrations in weaning piglets. Asian J Anim Vet Adv, 8(3):502-510.

Wintrobe, M.M. (1967). Clinical hematology. 6th Edition PP., 414-419, Lea Febiger, hilade-lphia, S.A.

Zeedan, Kh., El-Malky O.M. and Komonna O.F. (2009). Productive and reproductive performance of buffaloes fed on rations supplemented with biogen zinc at late pregnancy period. Proc. of the 2nd Scientific of Animals Wealth Research in the Middle East \& North Africa, Pp. 237-294.

Zeedan, Kh., El-Malky, O.M., Komonna, O.F., AbdelLatif M.A. and Ebtehag I.M. Abouelenin (2008). Effect of biogen-zinc supplementation on some production, digestion, rumen fermentation and some blood parameters in buffalo. Egyptian J. Anim. Prod., 45 Suppl. Issue, Dec, 557-569.

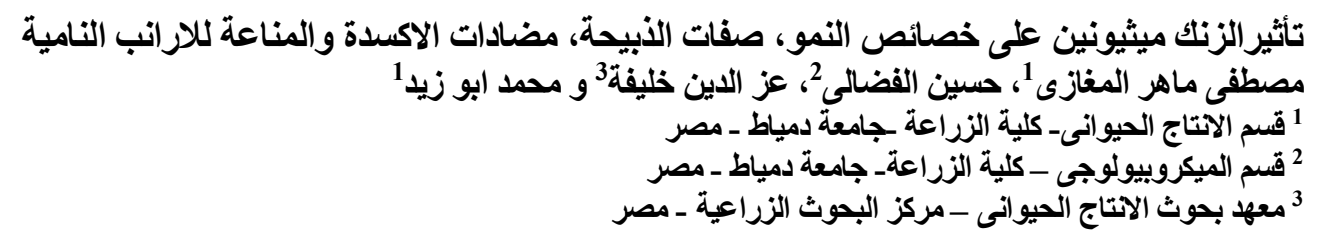

تهدف هذه الدراسة الى تقييم تأثير اضافة الزنك ميثيونين فى علائق الار انب النامية على خصائص النمو، صفات الذئي الذيحة، حالة مضادات الاكسدة،

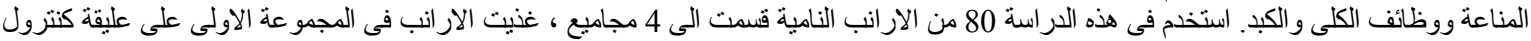

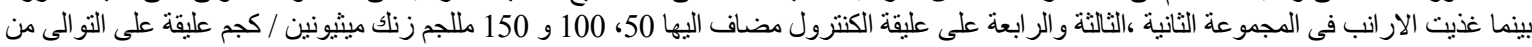

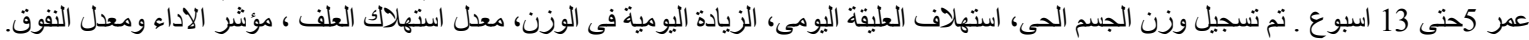

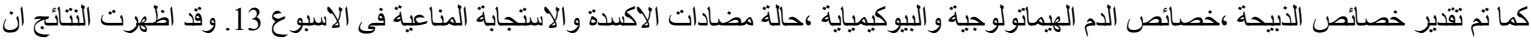

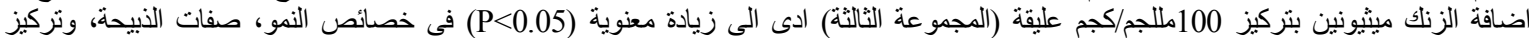

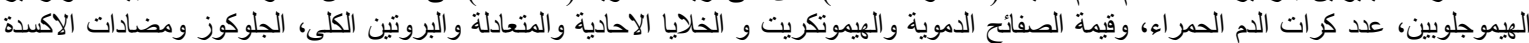

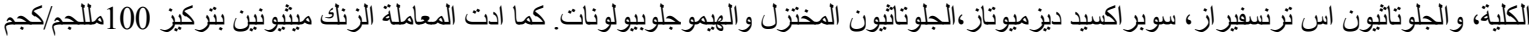

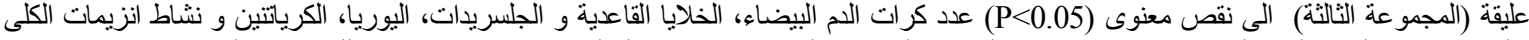

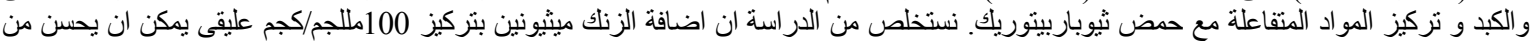

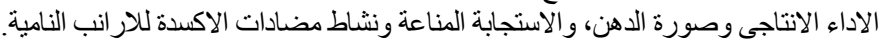

